OSOBA I WOLA

Filozofia Chrześcijańska • Tom 10, Poznań 2013

Unimersytet im. Adama Mickiewicza w Poznaniu • Wydziat Teologiczny

MAREK JĘDRASZEWSKI

Uniwersytet im. Adama Mickiewicza w Poznaniu

Wydział Teologiczny

Zakład Filozofii Chrześcijańskiej

\title{
Edyta Stein: wiara jako decyzja. Refleksje w świetle Augustyna, Kartezjusza, Husserla, Ingardena i Benedykta XVI
}

Edith Stein: Faith as Decision. Some Thoughts Inspired by Augustine, Descartes, Husserl, Ingarden and Benedict XVI

\section{DWA ZWROTNE MOMENTY}

W życiu Edyty Stein stosunkowo łatwo można zauważyć dwa zwrotne momenty w odniesieniu do wiary. Pierwszym z nich było zarzucenie przez nią praktyki modlenia się, do której - głównie dzięki swej matce, Auguście z domu Courant - była wychowywana i w której wzrastała przez kilkanaście lat. Nagle okazało się jednak, że pobożny, tradycyjny dom żydowskiej rodziny Steinów nie zabezpieczył jej przed konfrontacją $\mathrm{z}$ ateizmem - $\mathrm{i}$ to ateizmem głoszonym przez bardzo bliskie jej osoby: przez rodzoną siostrę Elzę, jak również przez jej męża Maxa. Wystarczył jeden tylko, nieco dłuższy wyjazd z rodzinnego Wrocławia w 1906 roku, gdy Edyta miała zaledwie 15 lat. Jak później wyznała w autobiografii,

czas spędzony w Hamburgu [...] był pewnym stadium przepoczwarzania się. [...] Czytałam, a także słyszałam o sprawach, które nie wychodziły mi na dobre. Specjalizacja zawodowa mego szwagra wymagała posiadania w bibliotece książek nie nadających się zupełnie na lekturę dla piętnastoletniej dziewczyny. Oprócz tego Max i Elza byli zdecydowanymi ateistami i w ich domu nie było śladu jakiejkolwiek religijności. Tutaj także całkiem świadomie i z własnej woli zaprzestałam się modlić1.

\footnotetext{
${ }^{1}$ E. Stein, Dzieje pewnej rodziny żydowskiej, tłum. J.I. Adamska, Kraków 2005, s. 179.
} 
Drugim zwrotnym momentem stało się wydarzenie, jakie miało miejsce 15 lat później, wczesną jesienią 1921 roku w Bad Bergzabern. Przebywając w domu swej przyjaciółki Hedwig Conrad-Martius, Edyta Stein stanęła przy szafie z książkami. Jak po latach wyznała, ,sięgnęłam na chybił trafił i wyciągnęłam grubą książkę. Nosiła ona tytuł: Życie św. Teresy z Ávila napisane przez nią samą. Zaczęłam czytać, zostałam zaraz pochłonięta lekturą i nie przerwałam, dopóki nie doszłam do końca. Gdy zamykałam książkę, powiedziałam do siebie: «To jest prawda!»"”. Rankiem tego samego dnia udała się do miejscowej księgarni, w której kupiła katolicki katechizm i mszał. W ten sposób rozpoczął się dla niej okres katechumenatu, który trwał do dnia 1 stycznia 1922 roku, kiedy w kościele parafialnym w Bad Bergzabern przyjęła chrzest.

Można by więc powiedzieć: życie wiary u Edyty Stein w jakiejś mierze decydowało się w konfrontacji z książkami: biblioteka szwagra w Hamburgu, Maxa, przyczyniła się do zarzucenia przez nią modlitwy, a w konsekwencji i wiary, natomiast książka znajdująca się w zbiorach przyjaciółki Hedwig Conrad-Martius do tego życia ją na nowo przywróciła. Nie była to jednak zwykła odyseja czy też powrót do tej samej rzeki: u Edyty Stein życie wiary, a przez to także i życie modlitwy nabrało bowiem w dużej mierze nowego kształtu, ponieważ od jesieni 1921 roku rozwijało się ono i kształtowało na łonie tego Kościoła-Matki, którym dla Edyty Stein stał się Kościół katolicki.

\section{DAS IST DIE WAHRHEIT!}

Ów moment pozytywnego przełomu, który równocześnie stał się u Edyty Stein powrotem do wiary w Boga, został jednoznacznie i precyzyjnie określony poprzez stwierdzenie, jakie padło z jej ust: Das ist die Wahrheit! - „To jest prawda!"

Jest to stwierdzenie, które bez wątpienia ma przede wszystkim wymiar historyczny, ponieważ zaistniało ono w konkretnym miejscu i czasie. Jednakże, jak się wydaje, zawiera ono w sobie jeszcze dwa wymiary: teoriopoznawczy i metafizyczno-religijny.

Wymiar teoriopoznawczy odsłania się przed nami, kiedy na stwierdzenie Edyty Stein Das ist die Wahrheit! - „To jest prawda!” spojrzymy w świetle filozofii Kartezjusza, a dokładniej poprzez ten decydujący udział, jaki w akcie poznania ma, według niego, sama wola. Zgodnie z tezą głoszoną przez ojca nowożytnego myślenia sąd, jaki wypowiada podmiot poznający, jest w swej wewnętrznej strukturze czymś bardzo złożonym, gdyż biorą w nim udział oby-

\footnotetext{
${ }^{2}$ Teresa Renata od Ducha Świętego, Edyta Stein. Filozof $i$ karmelitanka, tłum. M. Kaczmarkowski, Paris 1973, s. 61.
} 
dwie podstawowe zdolności umysłu: rozum i wola. Rozum, według Kartezjusza, jest zdolnością przedstawiania, natomiast sprawą woli jest twierdzenie lub zaprzeczanie. Dlatego też sąd nie jest aktem czysto intelektualnym, ale aktem pewnej decyzji, zgody lub niezgody na to, co woli przedstawia sam intelekt. To wola decyduje ostatecznie o tym, co można uznać za prawdę, a co za fałsz lub jakąś ułudę ${ }^{3}$. W tym kontekście należy postawić pytanie: na czym polega błąd. Według Kartezjusza wola ludzka jest, na sposób boski, nieograniczona, natomiast rozum jest ograniczony. Jeśli więc wola utrzymuje się w granicach, w których rozum daje podstawę do sądów, wtedy nie może się ona mijać z prawdą. Jeśli jednak wybiega poza tę granicę i wydaje sąd w odniesieniu do tego, gdzie rozum nie sięga, wtedy wpada w błąd. Jak bowiem czytamy w Zasadach filozofii, „to zaś, że popadamy w błędy jest zaiste niedoskonałością, tkwiącą w naszym działaniu czy używaniu wolności, nie zaś w naszej naturze; ona bowiem jest ta sama zarówno wtedy, gdy słusznie, jak i wtedy, gdy niesłusznie sądzimy"4. Chociaż bowiem oczywistą rzeczą jest to, że nikt nie chce się mylić, to jednak „nawet sama żądza uchwycenia prawdy sprawia bardzo często, że ci, co dobrze nie wiedzą, w jaki sposób można ją posiąść”, na skutek błędnej decyzji woli „wydają sądy o tych sprawach, których nie ogarniają, i dlatego też błądzą"5.

Jak wiemy z wielu świadectw osobistych Edyty Stein, przed momentem nawrócenia w Bad Bergzabern od strony intelektualnej znała ona już dobrze zasady chrześcijańskiej wiary, zwłaszcza potęgę Chrystusowego krzyża, która ukazała się jej w postawie Anny Reinach nieoczekiwanie postawionej w obliczu śmierci swego męża, Adolfa Reinacha. A jednak ciagle brakowało jej czegoś, co pozwoliłoby jej opowiedzieć się za realną prawdziwością chrześcijaństwa. Dopiero lektura autobiografii św. Teresy z Ávila sprawiła, że dokonał się w niej tak oczeki-

\footnotetext{
${ }^{3}$ Moje własne błędy zależą „od współdziałania dwóch przyczyn, a to od mojej zdolności poznawania i zdolności wybierania (a facultate eligendi) czy też wolności decyzji (ad arbitrii libertate), tzn. od intelektu i zarazem od woli. Przy pomocy bowiem samego intelektu ujmuje tylko te idee, o których mogą wydać sąd, i tak też w intelekcie tak właśnie pojętym nie może się znaleźć żaden błąd w właściwym tego słowa znaczeniu”. R. Descartes, Medytacje o pierwszej filozofii, tłum. M. i K. Ajdukiewiczowie, Warszawa 1958, t. 1, s. 74.

„Tak więc do sądzenia potrzebny jest wprawdzie intelekt, ponieważ o rzeczy, której w żaden sposób nie ujęliśmy, nie możemy niczego sądzić, ale potrzebna jest do tego także i wola, aby rzeczy w pewien sposób ujętej udzielić zgody”. R. Descartes, Zasady filozofii, tłum. I. Dąmbska, Warszawa 1960, s. 24.

${ }^{4}$ R. Descartes, Zasady filozofii, dz. cyt., s. 25.

${ }^{5}$ Por. tamże, s. 27-28

„Skądże więc biorą się moje błędy? Otóż tylko stąd, że woli, mającej szerszy zasięg niż intelekt, nie utrzymuję w tych samych granicach, lecz rozciągam ją także na te sprawy, których nie pojmuję. A ona będąc co do nich niezdecydowana, łatwo zbacza $z$ drogi prawdy i dobra; i w taki to sposób powstają moje błędy i grzechy”. R. Descartes, Medytacje o pierwszej filozofii, t. 1, dz. cyt., s. $77-78$.

Por. także: W. Tatarkiewicz, Historia filozofii, Warszawa 1983, t. 2, s. 53.
} 
wany i upragniony przez nią przełom. Z punktu widzenia teologii katolickiej trzeba by powiedzieć: to była chwila łaski. Natomiast z punktu widzenia Kartezjuszowej teorii poznania w jej stwierdzeniu Das ist die Wahrheit! - „To jest prawda!” należy dostrzec pewną decyzję woli, za którą, w konsekwencji, poszły następne decyzje: kupno katechizmu i mszału, a następnie prośba o chrzest w Kościele katolickim.

Obok wymiaru teoriopoznawczego w stwierdzeniu Edyty Stein należy również dostrzec istnienie wymiaru metafizyczno-religijnego. Jej sąd: Das ist die Wahrheit! - „To jest prawda!” prowadził bowiem do uznania tego faktu, że to, co głosi chrześcijaństwo, a dokładniej: to, co głosi Kościół katolicki, jest prawdą, i że, następnie, ta prawda ma wymiar ściśle osobowy. Jest nią Syn Boży, Jezus Chrystus.

Aby móc lepiej zrozumieć wymiar metafizyczny (jako pierwszy człon wymiaru metafizyczno-religijnego), należy - jak się wydaje - odnieść się tutaj do rozróżnienia, jakie często w swej filozofii stosował przyjaciel Edyty Stein ze studenckich jeszcze czasów spędzonych w Getyndze i Fryburgu Bryzgowijskim, Roman Ingarden. Jest to rozróżnienie między ontologią, zajmującą się istotą rzeczy, a metafizyką, która jest nauką o bytach realnie istniejących. Jak bowiem pisał Ingarden w Sporze o istnienie świata, ,obok zagadnień nauk szczegółowych [...] rodzi się żądanie całkiem nowej «nauki», pewnego rozważania czysto teoretycznego, a le zupełnie odmiennego od badań nauk szczegółowych i od $\mathrm{n}$ i c h $\mathrm{n}$ i e z a l e ż n g o". Nauka ta, zwana przez Ingardena ontologią, powinna zajmować się tak zwanymi rozważaniami ontologicznymi. W odróżnieniu od nauk szczegółowych, które zajmują się faktami,

rozważanie ontologiczne polega na apriorycznej analizie zawartości idei. Najistotniejsze swe uzasadnienie posiada ono w czystym uchwyceniu ostatecznych jakości idealnych (, czystych istot") i zachodzących między nimi związków koniecznych. Z drugiej strony jednak przedłuża się w analizę czystych możliwości, jakie dla indywidualnego bytu wynikają z tego, co stwierdzono w zawartościach idej. Badanie ontologiczne nie zakłada żadnego przedmiotowego faktu w szerszym tego słowa znaczeniu, a więc w szczególności ani istnienia realnego świata, ani przedmiotów w jego obrębie, ani też istnienia jakiejkolwiek dziedziny przedmiotowej określonej przez pewien układ aksjomatów ${ }^{7}$.

Tak rozumianej ontologii Ingarden przeciwstawiał metafizykę. W jego rozumieniu badania metafizyczne

\footnotetext{
${ }^{6}$ R. Ingarden, Spór o istnienie świata, t. 1, Warszawa $1987^{3}$, s. 41.

${ }^{7}$ Tamże, s. 45.
} 
stoją [...] z jednej strony w ścisłym związku z rozważaniami ontologicznymi, z drugiej jednak nie mogą one również pomijać wyników nauk szczegółowych o faktach. Dotyczą one bowiem dokładnie tych samych przedmiotów, którymi zajmują się te nauki, a tym się tylko od nich różnią, że starają się (p r z e z u w z g lę dnienie rozważań ontologicznych) uchwycić ich własności istotne, nie zadowalając się jakimikolwiek cechami, które akurat pojawią się w doświadczeniu 8 .

Wypowiadając stwierdzenie Das ist die Wahrheit! - „To jest prawda!”, Edyta Stein niewatpliwie wykroczyła poza ontologię w Ingardenowym znaczeniu tego terminu, a weszła w rzeczywistość metafizyki. Głoszony przez chrześcijaństwo Chrystus przestał być dla Edyty Stein jakąś możliwą ideą, lecz stał się konkretnym faktem, który ona uznała i w odniesieniu do którego zaczęła w pełni świadomie i konsekwentnie kształtować swoje dalsze życie. Gdyby odnieść to do jej życia modlitwy, należałoby powiedzieć, że od nocy swego nawrócenia zaczęła się na nowo modlić, a jej życie modlitewne stało się tak intensywne i głębokie, że dzisiaj uchodzi za jedną z najbardziej znaczących i wielkich mistrzyń modlitwy i kontemplacji w całym Kościele katolickim pierwszej połowy XX wieku.

Z kolei na wymiar religijny (jako drugi człon wymiaru metafizyczno-religijnego), który dostrzegamy w eksklamacji Edyty Stein Das ist die Wahrheit! - „To jest prawda!", zawierającej w sobie zarówno kartezjański element woli istniejący w samym akcie poznawczym, jak i opowiedzenie się za Osobową Prawdą - za Jezusem Chrystusem, wskazują następujące stwierdzenia Benedykta XVI znajdujące się w jego liście apostolskim Porta fidei:

Wiara jest decyzją na to, żeby być z Panem, aby z Nim żyć. To „bycie z Nim” wprowadza do zrozumienia powodów, dla których się wierzy. Wiara, właśnie dlatego, że jest aktem wolności, wymaga również odpowiedzialności społecznej za to, w co się wierzy. Kościół w dniu Pięćdziesiątnicy ukazuje z całą oczywistością ów wymiar publiczny wiary i głoszenia jej bez lęku każdej osobie. Jest to dar Ducha Świętego, który uzdalnia do misji i umacnia nasze świadectwo, czyniąc je śmiałym i odważnym?

W dalszym życiu Edyty Stein możemy bez trudu dostrzec jej nieustanne dojrzewanie w wierze i ciąłe poszukiwanie argumentów na rzecz rozumności samego aktu wiary. Wskazuje na to między innymi jej dyskusja z Ingardenem ${ }^{10}$. Oczywisty jest także u niej publiczny wymiar wiary, który doprowadził ją ostatecznie do najwyższego stopnia świadectwa - do martirium, jakie miało miejsce w dniu 9 sierpnia 1942 roku w komorach gazowych KL Auschwitz.

\footnotetext{
${ }^{8}$ Tamże, s. 43.

${ }^{9}$ Benedykt XVI, List apostolski Porta fidei, n. 10.

${ }^{10}$ Por. m.in. M. Jędraszewski, Edyta Stein. Filozof i laska wiary, Poznań 2003, s. 47-79.
} 


\section{KSZTAŁTOWANIE SIĘ WIERZACEGO „JA"}

Moment, w którym Edyta Stein wypowiedziała swoje słynne stwierdzenie Das ist die Wahrheit! - „To jest prawda!”, był równocześnie mocno osadzony w jej osobistej refleksji dotyczącej rozumienia własnego „Ja”. Była ona głęboko powiązana $\mathrm{z}$ analizami o charakterze ściśle fenomenologicznym, których autorami byli: najpierw jej mistrz, Edmund Husserl, a następnie ona sama. Kiedyś w liście do Ingardena powiedziała o sobie, że jej prace są zawsze odzwierciedleniem jej życia, ponieważ jest już tak skonstruowana, iż nie potrafi żyć bez refleksji ${ }^{11}$. Stąd także jej nawrócenie na katolicyzm musiało w niej szukać osobistego zrozumienia - zgodnie ze słynnym powiedzeniem Anzelma z Canterbury fides quaerens intellectum. Dlatego też musiała sobie postawić pytanie: $\mathrm{w}$ jaki sposób jej własne „Ja” mogło dojść do takiego momentu, w którym z całą świadomością mogła stwierdzić: „To jest prawda!”

Zapewne stało się to najpierw możliwe na skutek odejścia przez nią od tej koncepcji „Ja”, którą głosił Husserl w dziele zatytułowanym (w skrócie) Idee I, opublikowanym w $1913 \mathrm{roku}^{12}$. Była ona nierozerwalnie związana z proponowaną przez niego tak zwaną redukcją fenomenologiczna, czyli z $\varepsilon \pi \mathrm{o} \eta$. Chodziło $\mathrm{w}$ niej o wzięcie $\mathrm{w}$ nawias całego - w naturalnym nastawieniu doświadczanego - świata. „Traci [on] teraz dla nas - pisał Husserl w Ideach I - całą swą moc obowiązująca, winien zostać ujęty w nawias bez sprawdzania, ale także bez podawania w wątpliwość. W podobny sposób ten sam los winien spotkać wszystkie, choćby najlepsze, pozytywistyczne albo inaczej ugruntowane teorie i nauki odnoszące się do tego świata" ${ }^{13}$. W ramach tak rozumianej redukcji fenomenologicznej należało również wziąć w nawias istnienie Boga. Konieczne jest, jak twierdził Husserl, wyłączenie tego transcendensu, jakim jest Bóg, w imię absolutu świadomości, w imię dotarcia do tego pola badań, którym jest pole czystej świadomości ${ }^{14}$. W jakiejś mierze Bóg zakłócałby bowiem to pole, ponieważ „byłby [...] czymś «absolutnym» w pewnym zupełnie innym sensie niż absolut świadomości, tak jak z drugiej strony byłby czymś transcendentnym w zupełnie in-

\footnotetext{
${ }^{11}$ Por. list Edyty Stein do Romana Ingardena z dnia 15 października 1921 roku, w: E. Stein, Spór o prawde istnienia. Listy Edith Stein do Romana Ingardena, tłum. M. Klentak-Zabłocka, A. Wajs, Kraków 1994, s. 136.

${ }_{12}$ Dzieło to w thumaczeniu polskim ukazało się w 1975 roku jako: E. Husserl, Idee czystej fenomenologii i fenomenologicznej filozofii. Księga pierwsza, thum. D. Gierulanka, Warszawa 1975 (dalej E. Husserl, Idee I).

${ }_{13}^{13}$ Tamże, § 32, s. 94.

Niewykluczone, że można by spróbować zinterpretować proponowaną przez Husserla redukcję fenomenologiczną w duchu teorii poznania Kartezjusza jako próbę utrzymania woli w granicach, w których rozum daje podstawę do wydawanych przez nią sądów.

${ }^{14}$ Por. E. Husserl, Idee I, § 58, s. 176-178.
} 
nym sensie w przeciwstawieniu do transcendensu w sensie świata" ${ }^{15}$. Dlatego też Husserl bez jakichkolwiek wattpliwości stwierdzał: „Pomijamy to wszystko, co jeszcze ze strony religijnej świadomości - i to jako rozumowo uzasadniający motyw - może doprowadzić do tej samej naczelnej zasady"16.

Zagadnienia poruszone w Ideach I Husserl rozwijał w swoich późniejszych zapiskach i notatkach, których było bardzo wiele. Ich publikację zapowiadał zresztą we „Wprowadzeniu” do Idei I jako Idee II i jako Idee III ${ }^{17}$. Jak wiadomo, w latach 1917-1918 Edyta Stein była asystentką tego filozofa. W ramach zleconych przez niego zadań opracowywała ona liczne manuskrypty mistrza, przygotowując je do druku. Gdy praca była już właściwie ukończona, Edytę Stein spotkało wielkie rozczarowanie: Husserl sprzeciwił się jej publikacji. Dalszy ciąg Idei I ujrzał światło dzienne dopiero w 1952 roku jako dzieło pośmiertne twórcy fenomenologii, zatytułowane (w skrócie) jako Idee $I I^{18}$.

W każdym razie nie ulega żadnej wątpliwości, że Edyta Stein doskonale znała pogląqdy Husserla na temat świadomości, w tym także odnośnie do tego, że właśnie świadomość i tylko ona jest tym, co jest źródłowe i absolutne. Sama przecież Edyta Stein w jakiejś mierze przyczyniła się do opracowania między innymi tych sformułowań, które znajdują się w Ideach II:

Jedyne, co jest pierwotnie indywidualne, to świadomość [wzięta] konkretnie, wraz ze swoim Ja. Wszystko inne, co indywidualne, jest czymś przejawiającym się i zasadę swego zindywidualizowania ma w rzeczywistym i możliwym pojawianiu się, które ze swej strony wskazuje poza siebie na pewną indywidualną świadomość. [...] W samym Ja tkwi zindywidualizowanie źródłowe, absolutne. Ten sam duch nie może istnieć dwa razy, nawet nie może powrócić w ten sam całościowy stan i w tym jedynie pokazać swoje zindywidualizowanie, że z tą samą treścią występuje w różnych związkach ${ }^{19}$.

W tym samym czasie, kiedy była asystentką Husserla, Edyta Stein pracowała nad własnym, w pełni oryginalnym studium, które zatytułowała Psychische Kausalität. Ukończyła je w 1918 roku. Rok później przedstawiła je bez powodzenia na Uniwersytecie w Getyndze jako rozprawę habilitacyjną ${ }^{20}$. W rozpra-

15 Tamże, s. 177.

16 Tamże.

${ }^{17}$ Por. tamże, s. 10.

${ }^{18}$ Husserlowe Idee II przygotowała ostatecznie do publikacji Marly Biemel, opierając się na opracowaniach Edyty Stein (z lat 1917-1918) i Ludwiga Landgrebe'a (z lat 1924-1925). Dzieło ukazało się w Hadze w 1952 roku jako IV tom Husserliana. W wersji polskiej zostało wydane w 1974 roku jako: E. Husserl, Idee czystej fenomenologii i fenomenologicznej filozofii. Księga druga, thum. D. Gierulanka, Warszawa 1974 (dalej E. Husserl, Idee II).

${ }^{19}$ E. Husserl, Idee II, § 64, s. 422, 423.

${ }^{20}$ Rozprawa Edyty Stein Psychische Kausalität została opublikowana w 1922 roku w „Jahrbuch der Philosophie und phänomenologische Forschung" (V, 1922, 1-293) wraz z inną jej pracą 
wie tej można znaleźć dwa niezwykle ważne fragmenty. Pierwszy z nich mówi o swoistej bliskości wiary w jej życiu. Z drugiej jednak strony bierze ją niejako w nawias, zgodnie z metodologicznymi założeniami Husserla dotyczącymi redukcji fenomenologicznej, dla którego była ona „królewską drogą” prowadząca w kierunku uznania świadomości jako jedynej źródłowości własnego Ja. „Robię plany na dalsze życie - pisała Edyta Stein w Psychische Kausalität - i z uwagi na nie kieruję życiem obecnym, jestem jednak w głębi duszy przeświadczona, że wydarzy się coś, co wszystkie me plany wyrzuci na śmietnik. Nie przyzwalam na tę autentyczną, żywą wiarę i nie pozwalam jej na siebie oddziaływać"21. Sformułowania: „Nie przyzwalam”, „Nie pozwalam jej na siebie oddziaływać” - to inne określenia na Husserlową redukcję fenomenologiczną. Poprzez nie Edyta Stein pozostaje zatem wierna temu, co o czystym, źródłowo absolutnym „Ja” pisał w Ideach II Husserl.

Natomiast drugi fragment rozprawy Psychische Kausalität wskazuje na to, że Edyta Stein odchodzi już od koncepcji absolutnie źródłowego „Ja”. Co więcej, wbrew postulatom Husserla Edyta Stein bynajmniej nie bierze w nawias tego transcendensu, którym jest Bóg. Więcej jeszcze: przypisuje Bogu w aktywności „Ja” rolę źródłową. Stwierdzając to wszystko, Edyta Stein odnosi się przy tym do jakiegoś osobistego doświadczenia.

Istnieje pewien stan spoczywania w Bogu, stan pełnego odprężenia wszystkich sił duchowych, w którym nie robimy żadnych planów, nie podejmujemy decyzji - naprawdę nie działamy; całą przyszłość zdajemy na wolę Bożą, pozostawiając ją całkowicie losowi; taki stan był chyba moim udziałem wtedy, gdy jakieś przeżycie, które przerastało me siły, pochłonęło całkowicie moje siły życiowe i pozbawiło mnie wszelkiej aktywności. Spoczywanie w Bogu było we mnie śmiertelną ciszą. Na jej miejsce pojawiło się poczucie bezpieczeństwa, zawieszenie wszelkiej troski, odpowiedzialności i konieczności działania. A gdy poddawałam się temu uczuciu, zwolna poczynało napełniać mnie nowe życie i popychać - bez jakiegokolwiek napięcia mej woli - do nowej działalności. Ten ożywczy przypływ jawił się jako emanacja aktywności i siły, która nie była moja, a która - nie stawiając żadnych wymagań mojej sile zaczyna we mnie działać. Jedynym warunkiem takiego odrodzenia duchowego zdaje się być bierna chłonność - tak jak jest ona zakorzeniona w strukturze osoby ${ }^{22}$.

Ponieważ była tak skonstruowana, że nie mogła uwolnić się od (auto)refleksji, Edyta Stein próbowała od strony filozoficznej zrozumieć i wyrazić to przełomowe wydarzenie, na skutek którego doszło w niej do opowiedzenia się za Bo-

pt. Individuum und Gemeinschaft jako Beiträge zur philosophischen Begründung der Psychologie und der Geisteswissenschaften.

${ }^{21}$ E. Stein, Psychische Kausalität, w: Teresa Renata od Ducha Świętego, Edyta Stein. Filozof $i$ karmelitanka, thum. M. Kaczmarkowski, Paris 1973, s. 60.

${ }^{22}$ Tamże, s. 60-61. 
giem i za chrześcijańską wiarą głoszoną przez Kościół katolicki. W pisanym już w karmelitańskim klasztorze $\mathrm{w}$ Kolonii dziele Byt skończony a byt wieczny (1936) podkreśliła najpierw rolę rozumu i woli w procesie poznania, które równocześnie związane jest $\mathrm{z}$ otrzymywaniem przez człowieka pewnych danych i przyjęciem ich przez niego, co dokonuje się mocą decyzji woli, a zatem dzięki jego wolności. Jej interpretacja obydwóch władz duchowych człowieka, a zwłaszcza „stanie woli po stronie intelektu” wykazuje uderzające podobieństwo do teoriopoznawczej koncepcji Kartezjusza. Edyta Stein stwierdziła w nim bowiem:

Poznanie (w najszerszym znaczeniu tego słowa) jest zdobyciem lub posiadaniem znajomości [czegoś]. Oznacza to u stworzeń otrzymywanie (nie leżące w ich mocy, bo jest „dane” i zakłada dawcę) oraz przyjęcie, będące sprawą ich wolności. [...] Udział wolności w poznaniu staje się tym większy, im bardziej jest ona rzeczą rozumu, wnioskowania i sądzenia; uzyskanie poznania wymaga tu więcej osobistego wysiłku. Wzrasta też liczba racji za i przeciw przyzwoleniu, które staje się trudniejsze i pozostawia więcej miejsca dla wolnej decyzji. Choćby tak nie powinno być, to jednak w życiu duchowym odgrywa dużą rolę owo stat pro ratione voluntas. W wielu przypadkach nie jest to nawet ,nierozsądne”, lecz [po prostu] żadne inne rozwiązanie nie jest wtedy dla nas możliwe ${ }^{23}$.

Jest przy tym rzeczą oczywistą, że decyzja woli w sprawach odnoszących się do życia duchowego - a ta decyzja musi zapaść, nie można przecież przez całe życie pozostawać w stanie swoistego zawieszenia - niesie wraz z sobą pewne ryzyko. Stąd też w liście do Romana Ingardena, noszącym datę 20 listopada 1927 roku, Edyta Stein napisała: „Nie trzeba, byśmy aż po kres naszego żywota szukali dowodu prawomocności doświadczenia religijnego. Konieczne jest jednak, byśmy opowiedzieli się za lub przeciw Bogu. Tego się od nas wymaga: zdecydować się, nie otrzymując w zamian kwitu gwarancyjnego. Oto wielkie ryzyko wiary" 24 .

Jednakże decyzja woli w momencie opowiedzenia się za Bogiem dokonuje się w szczególnej przestrzeni, wyznaczonej przez wolność, która odsłania się na działanie łaski Bożej. Wolność może, oczywiście, powiedzieć swoje „nie” wobec Boga. Jak Edyta Stein stwierdziła w rozprawie Ontyczna struktura osoby i jej problematyka teoriopoznawcza, napisanej około 1930 roku, a zatem kilka lat po swoim ciagle głęboko przeżywanym i reflektowanym nawróceniu, „dusza może zamknąć oczy na łaskę, [...] może usiłować uciec od łaski i od siebie"25. Dusza może jednak powiedzieć „tak” Bogu, czyli może otworzyć się na łaskę.

\footnotetext{
${ }^{23}$ E. Stein, Byt skończony a byt wieczny, thum. I.J. Adamska, Poznań 1995, s. 409-410.

${ }^{24}$ Taż, Spór o prawdę istnienia. Listy Edith Stein do Romana Ingardena, s. 195-196.

${ }^{25}$ Taż, Ontyczna struktura osoby i jej problematyka teoriopoznawcza, w: taż, Twierdza duchowa, thum. I.J. Adamska, Poznań 1998, s. 54.
} 
Według Edyty Stein będzie to możliwe pod warunkiem uznania i wcielenia w życie pewnego paradoksu: z jednej strony całkowitego zapomnienia o sobie, a z drugiej całkowitego pochwycenia siebie samej. Duchowe życie „Ja” zależy zatem od dwóch jego „działań”, mających dwa przeciwstawne sobie zwroty: pierwszym jest ruch „do wewnątrz” polegający na scaleniu się duszy, drugim natomiast jest ruch „na zewnątrz”, polegający na otwarciu się na działanie łaski Bożej. Zdaniem Edyty Stein, oprócz możliwości powiedzenia Bogu „nie”,

istnieje jeszcze ostatnia możliwość: przyjąć łaskę bez zastrzeżeń. Oznacza to zdecydowany odwrót duszy od siebie samej i bezwarunkowe zapomnienie o sobie (das Sichloslassen). Lecz aby móc siebie w ten sposób określić, dusza musi mocno siebie pochwycić i z najbardziej wewnętrznego centrum tak siebie całkowicie objać, żeby już nie mogła się zagubić. Oddanie siebie jest najbardziej wolnym aktem wolności. Ten, kto całkowicie bez troski o siebie, o swoją wolność i indywidualność odpowie na wezwanie łaski, ten wchodzi w nią zupełnie wolny z zachowaniem pełnej tożsamości. Nie wejdzie na tę drogę nikt, kto się ogląda na siebie ${ }^{26}$.

W dziele Byt skończony a byt wieczny, napisanym kilka lat później, Edyta Stein pogłębiła swoje refleksji dotyczące działania łaski w „Ja”. Owo „Ja” nie jest już bynajmniej Husserlowym „Ja” transcendentalnym, czyli świadomością będącą absolutną źródłowością, ale „Ja” konkretnej, wolnej osoby ludzkiej, do której zbliża się Bóg i którą wzywa do wewnętrznego otwarcia i przyjęcia Go. Spotkanie „Ja” z Bogiem jest spotkaniem dwóch wolnych osób. Jest to równocześnie spotkanie, które prowadzi do ich jedności - właśnie poprzez łaskę. Ona jest rodzajem pomostu między Bogiem a człowiekiem.

Łaska natomiast z Bogiem jednoczy: wnika w stworzenie nie odrywając korzeni od Boga i czyni je „winną latoroślą”. Jest to w pełnym znaczeniu możliwe tylko u stworzeń, które są wolne. Martwe przedmioty mogą stać się wprawdzie narzędziami boskiego działania i w tym znaczeniu zawierać w sobie łaskę (jak np. sakramenty), lecz nie mogą zostać „łaską napełnione” ani, jak osoba, być jej nosicielem. Łaska chce być przyjmowana „osobiście”. Jest ona wołaniem Boga i Jego pukaniem ${ }^{27}$, a wzywana osoba winna ją słyszeć i otworzyć się na nią; otworzyć siebie samą na Boga, który chce do niej wejść. Dlatego gotowość przyjęcia - potentia oboedientiae - w ścisłym i właściwym znaczeniu jest zdolnością do posłuszeństwa, do słuchania Boga i oddania się Mu w wolności. Jest to stosunek osoby do osoby i umożliwia owa jedność, jaka może istnieć tylko między osobami, tzn. bycie jednym dzięki połączeniu przez

${ }^{26}$ Tamże, s. 54-55.

W tych stwierdzeniach Edyty Stein można dosłyszeć się echa Chrystusowych słów: „kto chce zachować swoje życie, straci je; a kto straci swe życie z mego powodu, znajdzie je” (Mt 16,25).

${ }^{27}$ Sformułowanie to jest zapewne nawiązaniem do słów Chrystusa z Apokalipsy św. Jana: „Oto stoję u drzwi i kołaczę: jeśli kto posłyszy mój głos i drzwi otworzy, wejdę do niego i będę z nim wieczerzał, a on ze Mną" (Ap 3,20). 
łaskę. Łaska więc suponuje wolność i naturę, gdyż dla swego działania potrzebuje stworzeń wolnych ${ }^{28}$.

Prawdopodobnie w maju 1941 roku, przebywając w Karmelu w Echt, Edyta Stein napisała tekst modlitwy związanej z nowenną na Zesłanie Ducha Świętego. Zatytułowała go A ja pozostaję $z$ wami. W tej modlitwie, będącej hymnem do Ducha Świętego, zostały wyrażone przez Edytę Stein pewne nowe elementy odnoszące się do jej wizji człowieczego „Ja”. Jest w tym hymnie stosunkowo łatwo uchwytne echo słów św. Augustyna z jego Confessiones o Bogu, który jest interior intimo meo et superior summo meo. W języku polskim Zygmunt Kubiak oddał te słowa następująco: „A Ty byłeś bardziej wewnątrz mnie niż to, co we mnie było najbardziej osobiste, a zarazem wyżej nade mną, niż mogłem myślą sięgnąć kiedykolwiek" "29. Natomiast Edyta Stein zanosiła do Ducha Świętego następujące wezwanie: „Ty, bliższy mnie niż ja sobie / i bardziej wewnętrzny niż moje wnętrze, / a przecież nieuchwytny i niepojęty / rozsadzający każde imię: / / Duchu Święty - Wieczna Miłości!"30

Bliskie także filozofii św. Augustyna, a dokładniej: jego iluminizmu, są inne sformułowania Edyty Stein zawarte w tej samej modlitwie. Jak wiadomo, wbrew przesłaniu napisu, który znajdował się na frontonie świątyni Apollona w Delfach

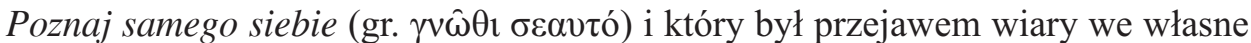
możliwości poznawcze człowieka, Augustyn twierdził, że prawdę możemy poznać jedynie dzięki Bożemu oświeceniu (illuminatio). „Kim jesteś słodkie Światło napełniające mnie / i rozświetlające mroki mego serca?" - zapytywała Ducha Świętego Edyta Stein i zaraz potem w duchu Augustynowego iluminizmu dawała sobie (i innym) odpowiedź: „Czyż nie jesteś jak promień, / który migoce z tronu wiecznego Sędziego / i wnika do nocy duszy, / która nigdy nie poznała samej siebie? / Miłosiernie i nieubłaganie / wnika do skrywanych zakątków"31.

Droga, jaką przebyła Edyta Stein w jej rozumieniu ludzkiego „Ja”, może być zatem określona jako droga od Husserla do Augustyna - od „Ja”, które jest absolutnie źródłowe i które konstytuuje przedmioty poznania, do „Ja”, które poddaje się Bożemu oświeceniu i którego najbardziej głębokie wnętrze jest równocześnie zamieszkiwane przez Boga.

Żeby jednak móc to powiedzieć, trzeba najpierw uwierzyć, a zatem w sposób wolny podjąc decyzję na rzecz wiary. W tym Edyta Stein była także podobna do Augustyna. Była zresztą tego w pełni świadoma już na początku swego

${ }^{28}$ E. Stein, Byt skończony a byt wieczny, s. 408.

${ }^{29}$ Augustyn, Wyznania 3, 6, 11; thum. Z. Kubiak, Warszawa 1982, s. 40.

${ }^{30}$ E. Stein, A ja pozostaję z wami. Z nowenny na Zestanie Ducha Świętego, w: J.I. Adamska, Sól ziemi. Rzecz o Edycie Stein, Poznań 1997, s. 199.

${ }^{31}$ Tamże, s. 200. 
chrześcijańskiego życia. Dnia 20 listopada 1927 roku, a zatem zaledwie sześć lat po radosnym stwierdzeniu w Bad Bergzabern: Das ist die Wahrheit! - „To jest prawda!”, pisała w Speyer w liście do Ingardena: „Droga wiedzie od wiary do oglądu, nie odwrotnie. Ten, co jest zbyt pyszny, by się tą furtką przeciskać, pozostaje na zewnątrz. Ten jednak, kto przedostaje się na drugą stronę, jeszcze za życia dociera do wciąż pełniejszej jasności i doświadcza dowodu maksymy: Credo ut intelligam"32.

\section{BIBLIOGRAFIA}

Augustyn, Wyznania, thum. Z. Kubiak, Warszawa 1982.

Benedykt XVI, List apostolski Porta fidei.

Descartes R., Medytacje o pierwszej filozofii, tłum. M. i K. Ajdukiewiczowie, Warszawa 1958, t. 1.

Descartes R., Zasady filozofii, tłum. I. Dąmbska, Warszawa 1960.

Husserl E., Idee czystej fenomenologii i fenomenologicznej filozofii. Księga pierwsza, thum. D. Gierulanka, Warszawa 1975.

Husserl E., Idee czystej fenomenologii i fenomenologicznej filozofii. Księga druga, thum. D. Gierulanka, Warszawa 1974.

Ingarden R., Spór o istnienie świata, t. 1, Warszawa $1987^{3}$.

Jędraszewski M., Edyta Stein. Filozof i łaska wiary, Poznań 2003.

Stein E., A ja pozostaję z wami. Z nowenny na Zesłanie Ducha Świętego, w: J.I. Adamska OCD, Sól ziemi. Rzecz o Edycie Stein, Poznań 1997, s. 199-202.

Stein E., Byt skończony a byt wieczny, tłum. I.J. Adamska, Poznań 1995.

Stein E., Dzieje pewnej rodziny żydowskiej, tłum. J.I. Adamska, Kraków 2005.

Stein E., Ontyczna struktura osoby i jej problematyka teoriopoznawcza, w: taż, Twierdza duchowa, thum. I.J. Adamska, Poznań 1998, s. 37-92.

Stein E., Psychische Kausalität, w: Teresa Renata od Ducha Świętego, Edyta Stein. Filozof $i$ karmelitanka, thum. M. Kaczmarkowski, Paris 1973, s. 60-61.

Stein E., Spór o prawdę istnienia. Listy Edith Stein do Romana Ingardena, thum. M. Klentak-Zabłocka, A. Wajs, Kraków 1994.

Tatarkiewicz W., Historia filozofii, t. 2, Warszawa 1983.

Teresa Renata od Ducha Świętego, Edyta Stein. Filozof i karmelitanka, thum. M. Kaczmarkowski, Paris 1973.

\footnotetext{
${ }^{32}$ E. Stein, Spór o prawdę istnienia, dz. cyt., s. 196.
} 


\section{SUMMARY}

There are two components of an act of religious faith: human will and God as truth and the Lord. Stein abandons Husserl's phenomenological reduction in the definition of human "self" for the sake of the influence of God, who shapes human "self". She stresses the role of the will besides of the mind. The will decides whether "self" can be shaped by God or not. In this way Stein favors Augustine's understanding of "self" ascribing to the will the leading role in process of finding truth about "self".

\section{Keywords}

act of faith, will, mind, truth, "self", epoché (phenomenological reduction), God, grace

\section{Słowa kluczowe}

akt wiary, wola, umysł, prawda, ,jaźn’”, epoche (redukcja fenomenologiczna), Bóg, łaska 